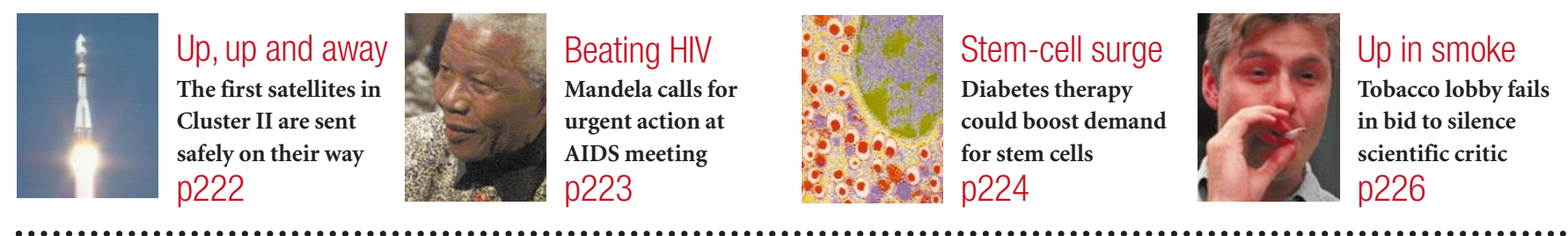

\title{
Large research facilities to lose out in science spending spree?
}

Colin Macilwain, Washington

It is not looking a good year to be a physicist — or even a biologist — who depends on facilities supported by the US Department of Energy. Once again, the department is set to miss out on the large increases in science spending expected to emerge from this year's budget round in Washington.

Scientific societies fear that the many physics subdisciplines sponsored by the department - as well as other scientists who use such facilities - could face a funding crunch this autumn, when the budget process for 2001 is completed.

In February, President Bill Clinton's administration proposed a large budget increase for the Office of Science at the Department of Energy (DoE). He also suggested increases for the other main federal agencies that support basic research, the National Science Foundation (NSF) and the National Institutes of Health (NIH).

Had Congress approved it, the proposal would have raised the Office of Science's funding by $12 \%$, to almost $\$ 3$ billion. About half of the increase would have paid for a new Spallation Neutron Source (SNS) at Oak Ridge National Laboratory in Tennessee.

But, as the appropriations process winds its way through Congress, it has become clear that the NIH will get far more than the 5\% increase requested by the administration. Lobbyists are confident that the NSF might also get close to the $17 \%$ budget boost that Clinton requested.

In contrast, the DoE's science programmes have drawn the short straw. "DoE is the one that is really hurting right now," says David Schutt, head of government affairs at the American Chemical Society.

Last month, the House of Representatives passed a bill that would have reduced construction funding for the SNS from $\$ 280$ million to $\$ 100$ million, and also cut support for the Basic Energy Sciences and Biological and Environmental Research divisions at the Office of Science.

DoE officials say that the reductions would damage the department's ability to serve the growing demand from NIHfunded biologists for its large facilities.

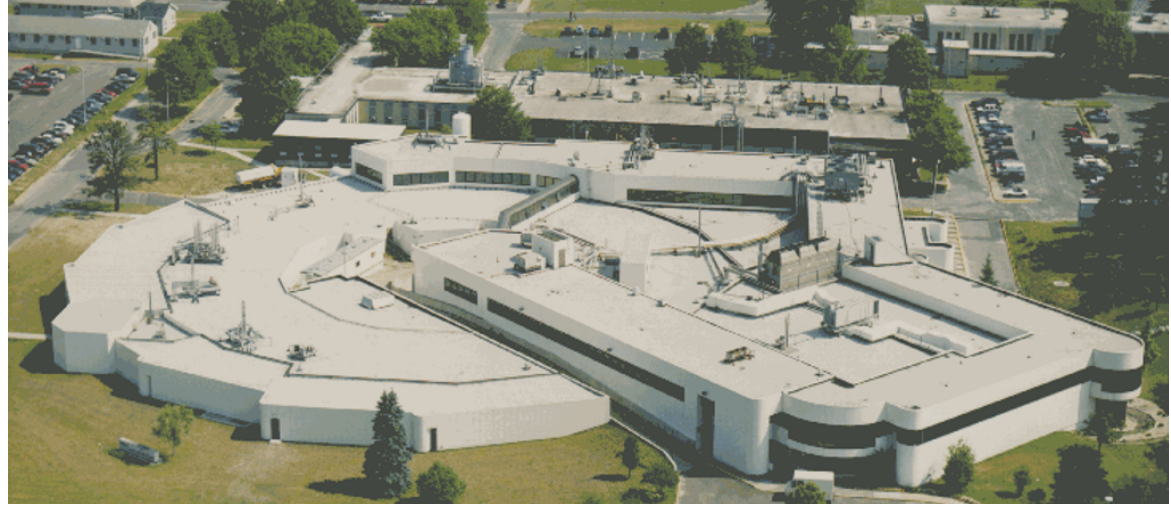

In demand: biologists are the biggest users of the Brookhaven's synchrotron light source.

At the National Synchrotron Light Source at the Brookhaven National Laboratory in New York, for example, biologists studying protein structure are now the largest user group. "I don't think it is appreciated what an important role DoE now plays in the biological sciences," says Brookhaven's director John Marburger.

Last week, the Senate appropriations subcommittee for Energy and Water, chaired by
Senator Pete Domenici (Republican, New Mexico), passed a plan that would reprieve each of these programmes but instead cut the core physics programmes at the agency.

Under the Senate plan, high-energy physics - already struggling to live with Clinton's request (see Nature 404, 909; 2000) — would lose $\$ 40$ million; nuclear physics and fusion would each lose \$20 million.

The stand-off between these two versions

\section{Jordan chosen to open SESAME}

\section{Heather McCabe}

The Middle East's international synchrotron research facility, which will bring together scientists from at least 11 countries, has finally been given a home. The new centre will be in Jordan, at a site halfway between the country's capital, Amman, and the West Bank.

The synchrotron has been donated by the German government (see Nature 399, 507-508; 1999). Given sufficient funding, it will be rebuilt on property owned by the Al-Balqa' Applied University in Al-Salt.

The site was formally approved last month by the interim council of the project, known as SESAME (Synchrotron-light for Experimental Science and Applications in the Middle East). Armenia, Cyprus, Egypt, Greece, Iran, Israel, Jordan, Morocco, Oman, the Palestinian Authority and Turkey are already backing the project, and Bahrain, Yemen and Tunisia have expressed their intention to join.

"The project represents a general enthusiasm for collaboration in the Middle East," says Siegbert Raither, director of mathematics, physical and chemical sciences at the United Nations Educational, Scientific and Cultural Organization, which is overseeing the project.

Jordan has agreed to pay US\$1 million per year in operating costs, and member countries are expected to give US\$50,000 per year for the three years of construction.

But more funds are still needed for the project. Organizers are hoping for assistance from the US and European programmes for peace in the region. 
- of the Energy and Water appropriations bill worries science lobbyists for at least three reasons: the bill is clearly short of money, there is pressure to pass it quickly, and, most importantly, the administration has decided not to veto it.

Domenici would like to sit on the bill until after the August recess, in the hope

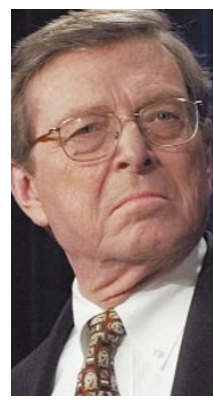
that it could share in the extra money that Congress and the administration are expected to find in September. But the Congressional leadership wants the Energy and Water bill passed quickly.

Mike Lubell, head of government affairs at Domenici: trying the American Physical to hold out for Society, predicts that extra money. the House and the Senate will split their differences without providing any extra money - leaving most programmes in the Office of Science facing modest but painful cuts.

Scientific societies are trying to prevent this. But the DoE's science programmes are vulnerable following its security problems with nuclear weapons and fierce clashes between Congressional leaders and its secretary, Bill Richardson.

The Senate has proposed a $\$ 2.7$ billion increase for the NIH, and it is thought that, after late budget negotiations, this is what it will get.

\section{UK space strategy slammed as lacking funds and vision}

\section{Natasha Loder, London}

Britain's traditional reluctance to make the same political commitment to space-based activity as its main economic competitors, which has been long criticized by the space community, has now come under strong attack from a cross-party group of Members of Parliament (MPs).

The House of Commons trade and industry select committee has been assessing space policy since last November. In its report, published last week, it says Britain's space strategy is limited in ambition, lacks leadership and is in urgent need of more money - and a radical rethink about how it is spent.

Much of the report focuses on the activities of the British National Space Centre (BNSC), the interdepartmental body set up in 1985 to coordinate the activities of the different parts of government interested in space.

The BNSC is an improvement over previous "ramshackle arrangements" and is successful at a European level, says the MPs' report. But the committee of MPs had received persistent complaints that the agency was failing to coordinate space activities because individual government departments wanted to keep control of their contributions.

The MPs now say the agency should be more proactive, that its role and organiza-

\section{Cluster leaves the ground — at last}

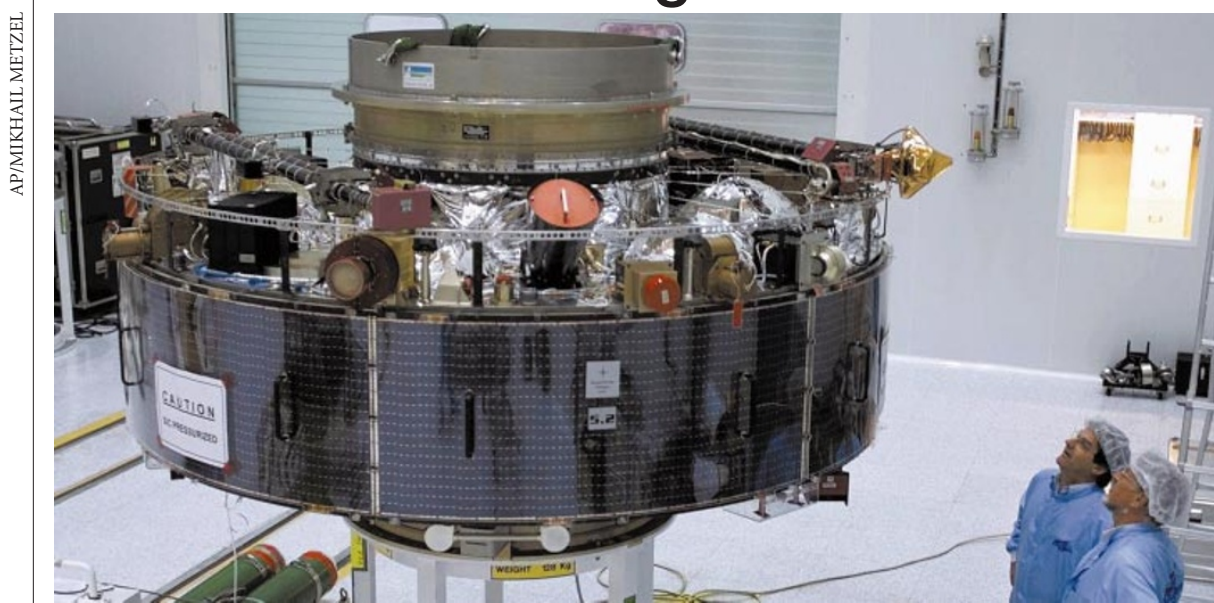

In waiting: French engineers inspect one of the Cluster satellites prior to its launch last Sunday.

After a nerve-wracking 24-hour delay, scientists are celebrating the successful launch of two of the four Cluster II satellites that will fly in formation around the Earth, sending back data on the weather in space. They were launched on Sunday at Baikonur Cosmodrome in Kazakhstan, after a last- minute hitch forced take-off to be postponed. The second pair of satellites will be launched on 9 August. Later this year scientists should start gathering data from the satellites on the structure of the Earth's magnetic field and the flow of charged particles trapped within it.

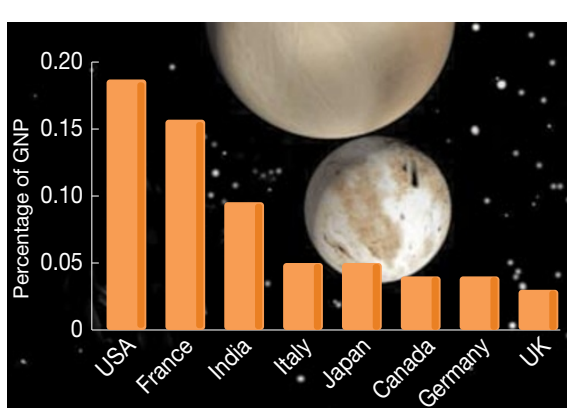

Lagging behind: latest figures put Britain's space spending at the bottom of the world league.

tion should be radically reviewed, and that it should produce annual reports. Also, thought must be given to whether it - or its successor - should have its own budget. Without this, say the MPs, the BNSC's "hands have been tied".

Ian Halliday, chief executive of the Particle Physics and Astronomy Research Council (PPARC), one of the agency's partners, says the BNSC's performance is "effective but not inspirational". This view is shared by Halliday's predecessor Ken Pounds, head of astronomy at Leicester University. Pounds says that for the past 15 years, Britain's attitude to space has been "far too cautious and conservative".

Halliday is also critical of how little money is spent on space science: $\mathfrak{1} 30$ million of PPARC's contribution to the BNSC goes on membership of the European Space Agency (ESA), and the rest is spent on instruments. Halliday describes ESA membership as comparable to belonging to a golf club while being able to afford only half a set of clubs.

Evidence presented to the select committee shows that Britain's public investment in space $\mathrm{R} \& \mathrm{D}$ is low in absolute and relative terms (see figure). The United Kingdom Industrial Space Committee — the British space industry's trade association - told MPs that "all the main space nations have increased their investment in space in recent years, whereas UK investment has at best remained static".

Although the MPs questioned the proportion of national spending on space compared with contributions to ESA, they also warned strongly against cutting ESA funding. They said this would seriously damage the UK space industry - about $80 \%$ of PPARC's contribution to ESA returns to British industry in the form of contracts.

But the MPs do not see greater collaboration with ESA as the best way forward. If the UK space budget were increased, they say, close consideration should be given to whether Britain would do better through bilateral arrangements with NASA, Japan, France, Germany or Sweden. 